Jurnal Independent Fakultas Hukum

\title{
ASPEK PERTANGGUNGJAWABAN PENGEMUDI OJEK ONLINE DALAM KASUS KECELAKAAN YANG MELIBATKAN PENUMPANG DILIHAT DARI HUKUM PERLINDUNGAN KONSUMEN
}

\author{
Dhevi Nayasari Sastradinata \\ Fakultas Hukum, Ilmu Hukum, Universitas Islam Lamongan \\ dhevinss@gmail.com
}

\begin{abstract}
ABSTRAK
Ojek merupakan sarana transportasi darat yang menggunakan kendaraan roda dua dengan berpelat nomor hitam, untuk mengangkut penumpang dari satu tujuan ke tujuan lainnya kemudian menarik bayaran. Ojek online telah menjadi angkutan umum favorit bagi sebagian masyarakat karena fleksibel dalam kegiatannya, bisa menjangkau tempat yang tidak dilalui angkutan umum seperti angkutan kota (angkot), bus, atau jenis angkutan umum beroda empat lain. Secara de facto, keberadaan ojek sepeda motor dianggap sangat membantu masyarakat dalam memecahkan kendala terhadap tersedianya angkutan umum sebagai angkutan alternatif. Namun secara de jure, keberadaan ojek sepeda motor dianggap bermasalah dalam hal lgalitas, karena secara normatif tidak memiliki hukum yang mengatur ojek sepeda motor secara jelas
\end{abstract}

\section{Kata Kunci : Ojek Online,Pertanggungjawaban Hukum, Perlindungan Konsumen}

\section{PENDAHULUAN}

Transportasi atau pengangkutan merupakan bidang kegiatan yang sangat penting dalam kehidupan masyarakat Indonesia. Dengan menyadari pentingnya peranan transportasi, maka lalu lintas dan angkutan jalan harus ditata dalam suatu sistem transportasi nasional secara terpadu dan mampu mewujudkan ketersediaan jasa transportasi yang sesuai dengan tingkat kebutuhan lalu lintas dan pelayanan angkutan yang tertib, nyaman, cepat, lancar dan berbiaya murah.

Manusia sebagai mahluk sosial mempunyai banyak kebutuhan yang harus dipenuh untuk kesejahteraan hidupnya. Kebutuhan tersebut tidak dapat terpenuhi dalam satu lokasi, oleh karena itu manusia memerlukan transportasi untuk melakukan perpindahan orang dan/atau barang dari satu tempat ketempat yang lain dengan menggunakan kendaraan.

Secara umum, di Indonesia jenis transportasi ada tiga, yaitu transportasi darat, transportasi laut, dan tansportasi udara. Dari ketiga jenis transportasi tersebut, transportasi angkutan jalan darat merupakan media yang paling sering digunakan oleh penumpang bila dibandingkan dengan transportasi lainnya.

Karakteristik transportasi orang dapat dibedakan menjadi angkutan pribadi dan angkutan umum. Angkutan umum paratransit merupakan angkutan yang tidak memiliki rute dan jadwal yang tetap dalam beroperasi disepanjang rutenya, sedangkan 
Jurnal Independent Fakultas Hukum

angkutan umum masstransit merupakan angkutan yang memiliki rute dan jadwal yang tetap serta tempat pemberhentian yang jelas.

Ojek online telah menjadi angkutan umum favorit bagi sebagian masyarakat karena fleksibel dalam kegiatannya, bisa menjangkau tempat yang tidak dilalui angkutan umum seperti angkutan kota (angkot), bus, atau jenis angkutan umum beroda empat lain. Ojek online bisa masuk dan melalui gang-gang sempit, jalan-jalan kecil, sehingga mampu menyediakan layanan door to door. Bahkan ojek sepeda motor dinilai cepat, lincah dan efisien untuk melewati maupun menghindari kemacetan di jalan. Secara de facto, keberadaan ojek sepeda motor dianggap sangat membantu masyarakat dalam memecahkan kendala terhadap tersedianya angkutan umum sebagai angkutan alternatif. Namun secara de jure, keberadaan ojek sepeda motor dianggap bermasalah dalam hal legalitas, karena secara normatif tidak memiliki hukum yang mengatur ojek sepeda motor secara jelas.

Undang-Undang Nomor 22 Tahun 2009 tentang Lalu Lintas dan Angkutan Jalan Bab X tentang angkutan Pasal 137 ayat (2) jo Pasal 3 ayat (2) Peraturan Pemerintah Nomor 74 Tahun 2014 menyatakan bahwa pengangkutan orang dan/atau barang dapat dilakukan dengan menggunakan kendaraan bermotor seperti sepeda motor, mobil penumpang, mobil barang dan mobil bus. Akan tetapi dalam bab yang sama pada bagian ketiga angkutan orang dengan kendaraan bermotor umum menggunakan mobil penumpang umum dan mobil bus umum. Meskipun keberadaan ojek sepeda motor dibutuhkan masyarakat sebagai salah satu pelayanan angkutan orang, tetapi sepeda motor tidak diatur oleh pemerintah beroperasi sebagai angkutan orang dengan kendaraan bermotor umum.

Tidak adanya pengaturan yang khusus mengenai ojek sepeda motor di dalam UU LLAJ maupun PP Nomor 74 Tahun 2014 tentang Angkutan Jalan mengakibatkan ketidakpastian hukum terkait dengan kedudukan ojek sepeda motor sebagai angkutan orang dengan kendaraan bermotor umum.

Hal ini berakibat juga pada tanggung jawab ojek sepeda motor terhadap penggunannya dari segi UU LLAJ, karena di satu sisi UU LLAJ mengatur kendaraan dalam Pasal 1 ayat (10) yang menyatakan bahwa kendaraan bermotor umum adalah setiap kendaraan yang digunakan untuk angkutan barang dan/atau orang dengan dipungut bayaran. Konsumen wajib dilindungi secara hukum melalui perundang-undangan yang jelas dan pasti, termasuk juga penyelesaian yang dapat 
Jurnal Independent Fakultas Hukum

ditempuh konsumen apabila mengalami kerugian terhadap penyelenggaraan jasa angkutan umum kendaraan bermotor ojek.

Salah satu kerugian yang dialami penumpang atau pengguna jasa ojek sepeda motor adalah terjadinya kecelakaan yang disebabkan oleh kesalahan pengemudi ojek sepeda motor. Kepastian hukum untuk memberi perlindungan kepada konsumen berupa perlindungan terhadap hak-hak konsumen, agar pelaku usaha tidak bertindak sewenang-wenang yang selalu merugikan konsumen

\section{METODE PENELITIAN}

Metode penelitian yang digunakan adalah Yuridis Normatif adalah penelitian yang memberikan penjelasan sistematis aturan yang mengatur suatu kategori hukum tertentu, menganalisis hubungan antara peraturan menjelaskan daerah kesulitan dan mungkin memprediksi pembangunan masa depan. ${ }^{2}$ Jenis pendekatan yang dilakukan oleh penulis adalah pendekatan perundangundang (statute approach) dan pendekatan konseptual (conceptual approach).

Pendekatan Perundang-Undangan (statute approach) adalah pendekatan yang dilakukan dengan menelaah semua

${ }^{1}$ Wijaya, Andika. 2016. Aspek Hukum Bisnis Transportasi jalan Online. Jakarta: Sinar Grafika. h. 10
Undang-Undang dan regulasi yang bersangkutan dengan isu hukum yang ditangani. $^{3}$ Sedangkan pendekatan konseptual (conceptual approach) beranjak dari pandangan dan doktrin yang berkembang di dalam ilmu hukum. Dengan mempelajari pandangan dan doktrin di dalam ilmu hukum, peneliti akan menemukan ide yang melahirkan pengertian hukum, konsep hukum, dan asas hukum relevan dengan isu yang dihadapi. ${ }^{4}$

\section{PEMBAHASAN}

Pengertian Konsumen menurut Pasal 1 ayat (2) UUPK adalah setiap orang pemakai barang/ jasa, yang tersedia dalam masyarakat, baik bagi kepentingan diri sendiri, keluarga, orang lain, maupun mahluk hidup lain dan tidak untuk diperdagangkan, menjelaskan bahwa berdasarkan Pasal 1 ayat (1) UUPK pengertian perlindungan konsumen adalah segala upaya yang menjamin adanya kepastian hukum untuk memberi perlindungan kepada konsumen.

Dari pengertian tersebut dapat disimpulkan bahwa hubungan konsumen dan pelaku usaha pada dasarnya adalah hubungan hukum yang menimbulkan hak dan kewajiban timbal balik antara

\footnotetext{
${ }^{2}$ Suggono, Bambang. 2007. Metodologi Penelitian Hukum. Jakarta: Grafindo, h.15

${ }^{3}$ Ibid.

${ }^{4}$ Ibid.
} 
Jurnal Independent Fakultas Hukum

keduanya. Alasan pengaturan perlindungan

konsumen dilatarbelakangi oleh hak-hak

konsumen, yakni

(1) menciptakan sistem perlindungan konsumen yang mengandung akses dan informasi, serta menjamin kepastian hukum;

(2) melindungi kepentingan konsumen pada khususnya dan kepentingan seluruh pelaku usaha pada umumnya;

(3) meningkatkan kualitas barang dan pelayanan jasa;

(4) memberikan perlindungan kepada konsumen dari praktik usaha yang menipu dan menyesatkan; dan

(5) memadukan penyelenggaraan, pengembangan dan pengaturan perlindungan konsumen dengan bidang-bidang perlindungan pada bidang-bidang lainnya.

Berdasarkan Pasal 2 UUPK, ada 5 (lima) asas dalam perlindungan konsumen, yakni (1)asas manfaat, (2) asas keadilan, (3) asas keseimbangan, (4) asas keamanan dan keselamatan konsumen, dan (5) asas kepastian hukum. Asas manfaat, mengamanatkan segala upaya dalam penyelenggaraan perlindungan konsumen harus memberikan manfaat sebesarbesarnya bagi perlindungan konsumen dan pelaku usaha secara keseluruhan. Asas keadilan, mengamanatkan agar partisipasi seluruh rakyat dapat diwujudkan secara maksimal dan memberikan kesempatan kepada konsumen dan pelaku usaha untuk

\footnotetext{
${ }^{5}$ Barkatullah, Abdul Halim. 2008. Hukum Perlindungan Konsumen. Bandung: Nusa Media, h.27
}

memperoleh hak-haknya serta melaksanakan kewajibannya secara adil. Asas kesimbangan, mengamanatkan untuk memberikan keseimbangan antara kepentingan konsumen, pelaku usaha dan pemerintah dalam arti materiil spiritual.

Asas keamanan dan keselamatan, mengamanatkan untuk memberikan jaminan atas keamanan dan keselamatan kepada konsumen dalam penggunaan, pemakaian, pemanfaatan barang atau jasa yang di konsumsi atau digunakan. Asas kepastian hukum, mengamantkan agar baik pelaku usaha maupun menaati hukum dan memperoleh keadilan dalam penyelengaraan perlindungan konsumen serta Negara menjamin kepastian hukumnya ${ }^{5}$.

Pasal 3 UUPK mengatur mengenai tujuan hukum perlindungan konsumen, sebagai berikut.

a. Meningkatkan kesadaran, kemampuan, dan kemandirian konsumen untuk melindungi diri.

b. Mengangkat harkat dan martabat konsumen dengan cara menghindarkannya dari ekses negatif pemakaian barang dan/atau jasa;

c. Meningkatkan pemberdayaan konsumen dalam memilih, menentukan dan menuntut hak-haknya sebagai konsumen.

d. Menciptakan sistem perlindungan konsumen yang mengandung unsur 
Jurnal Independent Fakultas Hukum

kepastian hukum dan keterbukaan informasi serta akses untuk mendapatkan informasi.

e. Menumbuhkan kesadaran pelaku usaha akan pentingnya perlindungan konsumen sehingga tumbuh sikap jujur dan bertanggungjawab dalam berusaha.

f. Meningkatkan kualitas barang dan/atau jasa yang menjamin kelangsungan usaha produksi barang dan/atau jasa, kesehatan, kenyamanan, keamanan dan keselamatan konsumen.

\section{Mahkamah Konstitusi (MK)}

menolak untuk melegalkan keberadaan ojek online sebagai sarana angkutan yang sah. Menurut putusan MK Nomor 41/PUU-XVI/2018, sepeda motor bukan kendaraan umum karena bukan kendaraan umum yang layak dari segi keselamatan. Hal ini mengacu pada Undang-Undang Lalu Lintas dan Angkutan Jalan. ${ }^{6}$

Tanpa dasar hukum yang sah, situasi ini merugikan semua pihak, baik konsumen maupun pengemudi ojek. Analisis data penelitian ini dilakukan pada berbagai sumber untuk menjawab rumusan masalah penelitian ini. Penelitian dilakukan dengan olah data melalui wawancara dengan pihak Dinas Perhubungan, Dit lantas Gresik, dan kantor cabang ojek online di kabupaten Gresik.

Hasil wawancara dengan pihak Dinas Perhubungan Gresik di bidang
Angkutan menghasilkan data yakni ojek online belum bisa dikatakan sebagai angkutan bermotor umum. Belum ada aturan yang jelas mengenai ojek online maupun ojek itu sendiri sehingga jika terjadi kecelakaan, maka yang bertanggung jawab atas kecelakaan tersebut adalah pengemudi ojek online itu sendiri. Dinas Perhubungan sebagai pemangku kebijakan transportasi tidak ikut bertanggung jawab.

Ojek online belum resmi jadi angkutan umum karena ojek online belum memenuhi syarat-syarat pendirian perusahaan angkutan umum. Syarat pendirian perusahaan angkutan umum akan menjadi sumber hukum administrasi bagi perusahaan ojek online dan Dinas Perhubungan bisa bertanggung jawab jika terjadi kecelakaan di jalan raya maupun masalah-masalah yang timbul di dalam Ojek Online itu sendiri. Permasalahan tersebut di antaranya adalah terkait pelayanan masyarakat sebagai kendaraan bermotor umum yang telah sah dan diakui pemerintah, khususnya Dinas Perhubungan sebagai pengelola angkutan jalan.

Proses wawancara berikutnya sebagai data penelitian ini adalah dengan pihak kepolisian resort Gresik, khususnya 
Jurnal Independent Fakultas Hukum

kepolisian lalu lintas (Polantas). Hasil wawancara dengan pihak Polantas, pihak Polantas sependapat dengan Dinas Perhubungan yaitu ojek online merupakan angkutan umum bermotor yang dapat dikatakan ilegal. Hal ini karena ojek online belum mendapatkan izin resmi dari dinas Perhubungan sehingga pengemudi ojek online beserta kendaraan bermotor yang digunakan dianggap sebagai kendaraan bermotor pribadi bukan kendaraan bermotor umum. Penegakan hukum pada kasus yang melibatkan ojek online disamakan dengan masyarakat pada umumnya. Hal ini akan berbeda jika ojek online sudah resmi menjadi angkutan umum.

Pihak ojek online, dalam hal ini yang diwawancarai adalah GOJEK, menjelaskan bahwa jika terjadi kecelakaan yang harus bertanggung jawab adalah pengemudi ojek online itu sendiri. Hal ini karena dalam perjanjian kerja antara GOJEK dengan mitra (pengemudi) dijelaskan bahwa mitra menyetujui bahwa semua risiko maupun kewajiban yang disebabkan oleh kelalaian mitra. Kelalaian oleh mitra tersebut yakni keterlambatan Mitra dalam menyediakan jasa kepada konsumen (penumpang) dan (2) kecelakaan dan kehilangan barang pada saat pengantaran yang mungkin timbul dari maupun sehubungan dengan penyediaan jasa oleh mitra kepada konsumen merupakan tanggung jawab Mitra.

Dalam perjanjian kerja antara GOJEK dengan mitra juga menyebutkan, dengan ini mitra membebaskan GOJEK dari segala macam tuntutan, gugatan, atau tindak hukum lainnya, baik dalam sebuah gugatan perdata maupun setiap tuntutan pidana yang dialami oleh mitra dalam bentuk apapun terkait dengan jasa yang ditawarkan maupun disediakan melalui aplikasi GOJEK. Jika ada informasi yang dapat membantu untuk proses investigasi seperti plat nomor, maka GOJEK hanya dapat membantu sebagai mediator dalam mempertemukan kedua belah pihak untuk mencari penyelesaian masalah tersebut.

Bentuk tanggung jawab pengemudi GOJEK atas terjadinya kecelakaan berupa ganti rugi kepada pihak penumpang. Sementara itu, GOJEK memberikan santunan musibah kecelakaan kepada seluruh pelanggan GOJEK yang menggunakan jasa Go-Ride (Jasa Angkutan Orang). Penumpang akan menerima penggantian sampai dengan $\mathrm{Rp}$. 10.000.000, dan untuk biaya rumah sakitnya sampai dengan Rp. 5.000.000, nominal tersebut dengan syarat dan ketentuan berlaku. ${ }^{7}$

\footnotetext{
${ }^{7}$ https://www.go-jek.com/faq\#accordion1
} 
Jurnal Independent Fakultas Hukum

\section{KESIMPULAN}

Perlindungan Hukum terhadap penumpang ojek online ketika terjadi kecelakaan dibedakan menjadi 2 yaitu perlindungan hukum preventif dan represif Perlindungan hukum preventif yaitu subjek hukum diberikan kesempatan untuk mengajukan keberatan atau pendapatnya sebelum suatu keputusan pemerintah mendapat bentuk yang definitif. Perlindungan hukum represif bertujuan untuk menyelesaikan sengketa, penanganan perlindungan hukum oleh pengadilan umum dan peradilan administrasi di Indonesia termasuk kategori perlindungan hukum ini.

\section{DAFTAR PUSTAKA}

Barkatullah, Abdul Halim. 2008. Hukum Perlindungan Konsumen. Bandung: Nusa Media

Suggono, Bambang. 2007. Metodologi Penelitian Hukum. Jakarta: Grafindo

Wijaya, Andika. 2016. Aspek Hukum Bisnis Transportasi jalan Online. Jakarta: Sinar Grafika. 